\title{
The genetic structure and mating system of Acrocomia aculeata (Arecaceae)
}

\author{
Aluana Gonçalves Abreu ${ }^{1}$, Regina Helena Geribello Priolli ${ }^{2}$, Joaquim Adelino Azevedo-Filho ${ }^{3}$, \\ Stella Maris Nucci ${ }^{2}$, Maria Imaculada Zucchi ${ }^{1}$, Ricardo Marques Coelho ${ }^{3}$ and Carlos Augusto Colombo ${ }^{3}$ \\ ${ }^{1}$ Agência Paulista de Tecnologia dos Agronegócios, Pólo Centro-Sul, Piracicaba, SP, Brazil. \\ ${ }^{2}$ Departamento de Genética, Escola Superior de Agricultura "Luiz de Queiroz", \\ Universidade de São Paulo, Piracicaba, SP, Brazil. \\ ${ }^{3}$ Instituto Agronômico, Campinas, SP, Brazil.
}

\begin{abstract}
Acrocomia aculeata is a perennial, fruit-producing palm tree, native to tropical forests. Its fruits have spurred interest because of their significant potential for use in the cosmetic industry and as feedstock for biofuel. In the present study, the genetic structure and mating system in Acrocomia aculeata were analyzed, using eight nuclear microsatellite loci and samples from São Paulo and Minas Gerais states, Brazil. By means of Bayesian analysis, these populations were clustered into two or three groups. A high multilocus outcrossing rate suggests that outcrosses were predominant, although a certain degree of biparental inbreeding also occurred. Thus, although monoecious and self-compatible, there is every indication that $A$. aculeata bears a mixed reproductive system, with a predominance of outcrossing. Given the genetic structure revealed hereby, future conservation strategies and germplasm collecting should be focussed on sampling and preserving individuals from different clusters.
\end{abstract}

Key words: SSR, mating system.

Received: June 25, 2011; Accepted: October 21, 2011.

The macaw palm (Acrocomia aculeata (Jacq.) Lood. ex Mart.), a perennial, fruit-producing palm-tree native to tropical forests, is widely distributed throughout Central and South America. In Brazil, it occurs in the states of Ceará, Minas Gerais, Mato Grosso, Mato Grosso do Sul and São Paulo, as well as the southern portions of the country (Scariot et al., 1995). It is encountered at high densities in pastures, where it is the dominant tree species (Scariot et al., 1991, 1995). Even so, distribution is restricted across its entire geographical range.

Acrocomia aculeata is an arborescent, spiny, single-stemmed palm. It can reach up to $16 \mathrm{~m}$ in height. It is monoecious and both beetle- and wind-pollinated, having been described as self-compatible (Scariot et al., 1991). Its fruits constitute a potential source of oil for the cosmetic industry and as feedstock biofuel.

Despite its economic potential, little is known about the reproductive biology, genetic structure and genetic diversity of natural populations of $A$. aculeata, studies having primarily focused either on its geographic distribution or the occurrence of pernicious species (e.g., Motta et al., 2002). The rapid degradation of natural areas throughout

Send correspondence to Regina Helena Geribello Priolli. Departamento de Genética, Escola Superior de Agricultura "Luiz de Queiroz", Universidade de São Paulo, Av. Pádua Dias 11, Caixa Postal 83, 13418-900 Piracicaba, SP, Brazil. E-mail: rpriolli@esalq.usp.br. southeast Brazil makes specific knowledge essential for the conservation and sustainable exploitation of this species. Thus, the aim was to describe the plant's genetic structure and estimate the mating rate in the families examined, by using eight nuclear microsatellite markers.

Only young leaves were collected from each plant. The samples were collected at least $100 \mathrm{~m}$ apart, to so avoid the inclusion of siblings. To assess genetic structure, 93 adults were sampled in ten locales of São Paulo State: Piquerobi $(\mathrm{N}=11)$, São Pedro do Turvo (hereafter SP Turvo, $N=5)$, São Simão $(N=10)$, Barbosa $(N=9)$, Santa Rosa (hereafter Sta Rosa, $N=8$ ), Mococa $(\mathrm{N}=7)$, Casa Branca (hereafter Cs Branca, $\mathrm{N}=5$ ) Amparo $(\mathrm{N}=10)$, Dourado $(\mathrm{N}=8)$ and Campinas $(\mathrm{N}=10)$, as well as one in Minas Gerais State - Ibituruna $(\mathrm{N}=10)$ (Figure 1). For studying the mating system, seedlings were collected around adult trees from nine maternal families in two towns in São Paulo State (Amparo and SP Turvo) and one in Minas Gerais State (Ibituruna) (Table 1).

Genomic DNA was isolated according to Doyle and Doyle (1990). The microsatellite primers and PCR conditions described in Nucci et al. (2008) were applied. Data, collected automatically with an ABI-377 sequencer, were analyzed by GeneScan/Genotyper software (Applied Biosystems), using ROX-500 as size-standard.

The assignment of individuals to populations and the individual admixture proportion were implemented in 


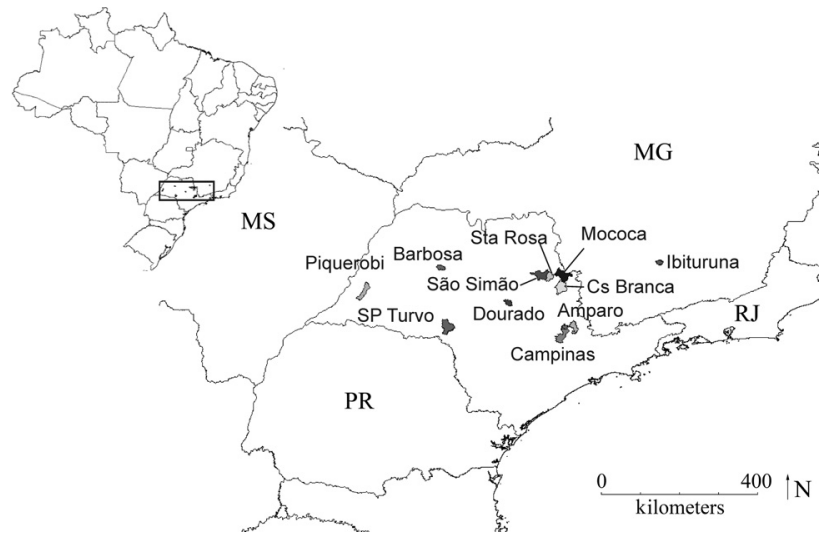

Figure 1 - Sampling localities. $\mathrm{MG}=$ Minas Gerais; $\mathrm{MS}=$ Mato Grosso do Sul; RJ = Rio de Janeiro; PR = Paraná

structure (Pritchard et al., 2000). The admixture model and an independent-allele-frequency model without prior population information were used. Following a burn-in period of 50,000 , ten independent runs were carried out for each value of $K$ (from 1 to 15 ), with 500,000 iterations. The true value of $K(\Delta K)$ was chosen according to Evanno et al. (2005).

Mating system analysis, employing the MLTR program (Ritland, 2002) was with the Expectation-Maximization method. The following parameters were estimated: $t_{m}$ (multilocus outcrossing rate), $t_{s}$ (unilocus outcrossing rate), $t_{m}-t_{s}$ (degree of biparental inbreeding), $r_{p}$ (paternity correlation), and $\mathrm{F}_{\mathrm{m}}$ (inbreeding coefficient of maternal parents). Standard errors were calculated based on 1000 bootstraps. As the outcrossing rate was estimated for seedlings in nature, there may be bias when compared to the real rates, due to inbreeding depression that could have occurred between mature seeds and established seedlings (Hufford and Hamrick, 2003; del Castillo and Trujillo, 2008).

When using the Bayesian-based approach, there was no single estimate for $K$ by which it was possible to clearly define the current macaw population structure. Two high $\Delta K$ values were observed, a first peak at $K=2$ and a second at $K=3$. At both of these, Piquerobi, São Simão, Sta Rosa, SP Turvo and Ibituruna could be mainly allocated to one of the resultant $K$ clusters, and the remainder to more than one (Figure 2). The individuals from São Simão and Sta Rosa

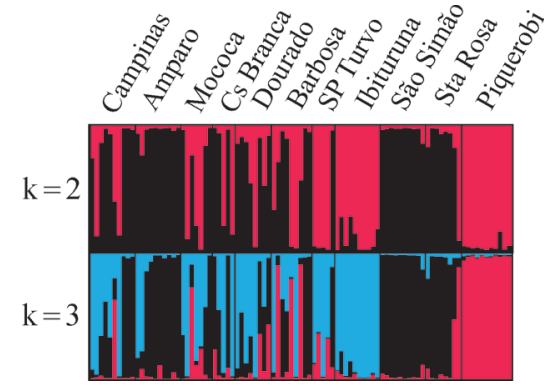

Figure 2 - The best clustering results $(K=2$ and $K=3)$ for Acrocomia aculeata samples. Each individual is represented by a vertical line partitioned into colored segments (black, red and blue), the length of which is proportional to the individual's cluster-membership coefficients.

belonged to cluster black ( $K=2,96 \%$ and $82 \% ; K=3,95 \%$ and $75 \%$, respectively), those from Piquerobi to cluster red $(K=2,95 \% ; K=3,95 \%)$ and those from Ibituruna to either cluster red $(K=2,95 \%)$ or blue $(K=3,95 \%)$.

Piquerobi, the westernmost population sampled, and far distant from the others, differed significantly from the remainder. This isolation could have caused the observed differentiation. Furthermore, Piquerobi is located on the border of the ranges of A. aculeata and A. totai (Lorenzi et al., 2010), whereby a certain degree of hybridisation can be expected. The populations of São Simão and Sta Rosa were also very different from the remainder. The two are located on a basaltic cuesta, on a landscape marked by hilly relief. Both sites are surrounded by escarpments that limit contact with other macaw-palm populations, this isolation possibly having led to genetic differentiation. Finally, Ibituruna is located in a different state, whereby the consequential limit in gene flow and enhancement of mutual genetic differentiation.

The multilocus outcrossing rate $\left(\mathrm{t}_{\mathrm{m}}\right)$ among families ranged from 0.73 to 1.0 , with an average of 0.65 , thereby presupposing a mixed mating system, with the predominance of outcrossing. The single-locus overall family estimate $\left(\mathrm{t}_{\mathrm{s}}\right)$ was 0.44 , which varied from 0.64 to 0.99 among families. The high $t_{m}$ values (0.73-1.0), confirming the mixed reproductive system as being characteristic of the macaw palm, is in accordance with a reproductive-biology study by Scariot et al. (1991). These values are comparable with those found for other tropical trees, which are generally outcrossers (e.g., Caryocar brasiliense $\left(\mathrm{t}_{\mathrm{m}}=1.0\right)$;

Table 1 - Mating system parameters in 9 families of Acrocomia aculeata from three localities and overall families (all): number of families (nf), total sample size $(N)$, multilocus outcrossing rate $\left(t_{m}\right)$, single-locus outcrossing rate $\left(t_{s}\right)$, outcrossing rate between related individuals $\left(t_{m}-t_{s}\right)$, correlation of paternity $\left(r_{p}\right)$ and inbreeding coefficient of maternal parents $\left(F_{m}\right)$. Standard errors in parentheses.

\begin{tabular}{lccccccc}
\hline Localities & $\mathrm{nf}$ & $\mathrm{N}$ & $\mathrm{t}_{\mathrm{m}}$ & $\mathrm{t}_{\mathrm{s}}$ & $\mathrm{t}_{\mathrm{m}}-\mathrm{t}_{\mathrm{s}}$ & $\mathrm{r}_{\mathrm{p}}$ & $\mathrm{F}_{\mathrm{m}}$ \\
\hline Amparo & 6 & 54 & $0.73(0.12)$ & $0.64(0.14)$ & $0.09(0.04)$ & $0.04(0.02)$ & 0 \\
Ibituruna & 2 & 13 & $1.00(0)$ & $0.99(0)$ & $0.01(0)$ & 0 & 0 \\
SP Turvo & 1 & 10 & $1.00(0)$ & $0.99(0)$ & $0.01(0)$ & 0 & 0 \\
All & 9 & 77 & $0.65(0.09)$ & $0.44(0.09)$ & $0.21(0.04)$ & $0.29(0.11)$ & 0 \\
\hline
\end{tabular}


Collevatti et al., 2001) and the palm tree Euterpe edulis $\left(\mathrm{t}_{\mathrm{m}}=0.90-0.98\right.$; Gaiotto et al., 2003)). Since A. aculeata is monoecious, it may possess some kind of self-incompatibility mechanism that limits self-pollination. In addition, as viability in seeds and seedlings produced by inbreeding is usually lower than in outcrossed individuals, inbreds may remain undetected due to large-scale, early mortality (Linhart, 2000). Notably, established seedlings were sampled in the present study.

The estimated $t_{m}-t_{s}$ overall family value $(0.21)$ indicated that, although the outcrossing rate is high, some cross-fertilization events do actually occur between close relatives. The low $r_{p}$ overall family value indicated both a low rate of correlated mating and that maternal seedlings are predominantly compounded by half-sibs. Multiple-paternity was expected since $A$. aculeata is wind-pollinated (Scariot et al., 1991), what might promote a high pollen carryover.

The lowest $t_{\mathrm{m}}$ value attributed to Amparo indicated a lower outcrossing rate than that found in other families, this possibly arising from biparental and uniparental (selfing) inbreeding. As this population is the most isolated, geographic isolation could hinder interpopulation gene flow, thereby enhancing inbreeding.

The results of this study indicate that, although monoic and self-compatible, A. aculeata has a mixed reproductive system, with a predominance of outcrossing. Nevertheless, there is a certain degree of biparental inbreeding, most likely due to the limited flight range of pollinators and restriction in seed dispersal. Although seeds can be dispersed by large animals (Zorzi BT (2009) Masters Thesis, Universidade Federal do Mato Grosso do Sul), most are dispersed by gravity, thereby remaining under the mother-tree, subsequently giving rise to the numerous seedlings actually observed thereabouts. Furthermore, as $A$. aculeata individuals are spatially distributed in clumps and beetle pollinators tend to forage inside these clumps, there is an increase in inter-relative mating. Given the genetic structure revealed by this study, future conservation strategies and germplasm collection for the macaw palm should focus on sampling and preserving individuals belonging to different clusters.

\section{Acknowledgments}

This research was supported by FAPESP (grant 05/56931-6).

\section{References}

Collevatti RG, Grattapaglia D and Hay JD (2001) High resolution microsatellite based analysis of the mating system allows the detection of significant biparental inbreeding in Caryocar brasiliense, an endangered tropical tree species. Heredity 86:60-67.

del Castillo RF and Trujillo S (2008) Effect of inbreeding depression on outcrossing rates among populations of a tropical pine. New Phytol 177:517-524.

Doyle JJ and Doyle JL (1990) Isolation of plant DNA from fresh tissue. Focus 12:13-15.

Evanno G, Regnaut S and Goudet J (2005) Detecting the number of clusters of individuals using the software structure: A simulation study. Mol Ecol 14:2611-2630.

Gaiotto FA, Grattapaglia D and Vencovsky R (2003) Genetic structure, mating system and long-distance gene flow in heart of palm (Euterpe edulis Mart.). J Hered 94:399-406.

Hufford KM and Hamrick JL (2003) Viability selection at three early life stages of the tropical tree, Platypodium elegans (Fabaceae, Papilionoideae). Evolution 57:518-526.

Linhart YB (2000) Variation in woody plants; molecular markers, evolutionary processes and conservation biology. In: Jain SM and Minocha SC (eds) Molecular Biology of Woody Plants. Kluwer, Dordrecht, pp 341-373.

Lorenzi H, Noblick L, Kahn F and Ferreira E (2010) Brazilian Flora: Arecaceae (Palms). Plantarum, Nova Odessa, 384 pp.

Motta PEF, Curi N, Oliveira-Filho AT and Gomes JBV (2002) Occurrence of macaúba in Minas Gerais, Brazil: Relationship with climatic, pedological and vegetation attributes. Pesq Agropec Bras 37:1023-1031.

Nucci SM, Azevedo-Filho JA, Colombo CA, Priolli RHG, Coelho RM, Mata TL and Zucchi MI (2008) Development and characterization of microsatellites markers from the macaw. Mol Ecol Resour 8:224-226.

Pritchard JK, Stephens M and Donnelly P (2000) Inference of population structure using multilocus genotype data. Genetics 155:945-959.

Ritland K (2002) Extensions of models for the estimation of mating systems using $\mathrm{n}$ independent loci. Heredity 88:221-228.

Scariot AO, Lleras E and Hay JD (1991) Reproductive biology of the palm Acrocomia aculeata in Central Brazil. Biotropica 23:12-22.

Scariot AO, Lleras E and Hay JD (1995) Flowering and fruiting phenologies of the palm Acrocomia aculeata: patterns and consequences. Biotropica 27:168-173.

Associate Editor: Dario Grattapaglia

License information: This is an open-access article distributed under the terms of the Creative Commons Attribution License, which permits unrestricted use, distribution, and reproduction in any medium, provided the original work is properly cited. 